\title{
Effect of lactation stage and milking frequency on milk yield from udder quarters of cows
}

\author{
M. Bogucki \\ UTP University of Science and Technology, Faculty of Animal Breeding and Biology, Department of Cattle Breeding, \\ Mazowiecka 28, 85-084 Bydgoszcz, Poland
}

(Received 25 April 2017; Accepted 17 October 2017; First published online 11 July 2018)

Copyright resides with the authors in terms of the Creative Commons Attribution 4.0 South African Licence.
See: http://creativecommons.org/licenses/by/4.0/za
Condition of use: The user may copy, distribute, transmit and adapt the work, but must recognise the authors and the South African
Journal of Animal Science.

\begin{abstract}
The aim of the study was to analyse daily milk yield from udder quarters of automatically milked primiparous and multiparous cows during lactation and with changing milking frequency. The daily milk yield of udder quarters was higher in multiparous than in primiparous cows. At the same time, differences were observed, especially in front and rear quarters, and also in left and right quarters. The front quarters (LF and $\mathrm{RF}$ ) of primiparous cows produced an average of 6.75 and $6.71 \mathrm{~kg}$ milk, and those of multiparous cows by 0.78 and $0.51 \mathrm{~kg}$ milk more, respectively. Higher daily milk yield was characteristic of rear quarters: $8.22 \mathrm{~kg}$ (left) and $7.71 \mathrm{~kg}$ (right) in primiparous cows, and 10.06 and $10.47 \mathrm{~kg}$ in multiparous cows, respectively. With advancing lactation (from $\leq 100$ to $>300$ days), the milk yield of all quarters was found to decrease. The lowest decrease was in left front quarters (by $3.40 \mathrm{~kg}$ ) and the highest in right rear quarters (by $4.35 \mathrm{~kg}$ ). This relationship was most evident in cows entering lactation (in the first lactation period of $\leq 100$ days). As milking frequency increased, the milk yield of individual quarters increased markedly. In front quarters, left and right quarters showed similar milk yields for milking frequency of less than 2.50 times/day and more than 2.80 times/day. A similar relationship was observed for rear quarters. The contribution of front and rear quarters to daily production was $45.8-54.2 \%$ in primiparous cows and $41.8-58.2 \%$ in multiparous cows.
\end{abstract}

Keywords: Milk, multiparous, primiparous, quarter milking

Corresponding author: bogucki@utp.edu.pl

\section{Introduction}

The use of modern technology in cattle breeding, especially that related to milk collection, provides access to current information about animals and milk parameters. It allows for rapid diagnosis of the early stages of mastitis, and detailed analysis of changes in milk composition and in milk production from different quarters. This information helps to implement effective dairy herd management strategies and makes for accurate selection decisions aiming to improve udder conformation (elimination of cows with divergent milk yields), which is particularly important in the context of preventing costly mastitis cases (Atasever \& Erdem, 2009; Forsbäck et al., 2010; Jędruś, 2013). The quantity and quality of milk produced depend directly on udder health (Pritchard et al., 2010; Szencziová et al., 2013). Udder health is influenced by morphological characteristics and physiological traits of the udder (Weiss et al., 2004; Tilki et al., 2005; Tancin et al., 2007b). For machine milking, the most appropriate udders are those with evenly developed quarters (Berglund et al., 2007; Tancin et al., 2007a). Bach \& Busto (2005), Berglund et al. (2007), Forsbäck et al. (2011) and Haghkhah et al. (2011) maintain that proper development of udder quarters is crucial to improving milk production efficiency in the cows. Stankūniené et al. (2008) showed that differences of more than $10-15 \%$ in milk yield between front and rear udders and of more than one minute in milking duration have a negative effect on udder productivity and health.

According to Kuczaj (2010), productivity of front and rear quarters in cows highly suitable for machine milking should constitute $42 \%$ and $58 \%$ of the total amount of milk produced, respectively. An earlier study by Weiss et al. (2004) cited the results of research showing that front quarters produce $39.4 \%$, and rear udders $60.6 \%$ of the milk drawn from the cow's mammary gland. Tančin et al. (2007b), who investigated differences in the milk yield of individual mammary quarters, showed that the right front quarters produced 
$22.04 \%$, left front quarters $22.23 \%$, right rear quarters $28.24 \%$ and left rear quarters $27.49 \%$ of the cow's total milk output.

In view of the continuously increasing milk production potential of cows and the increasingly advanced milk collection technologies, it is important to continually monitor the physiological adaptation of the cows to new milking conditions by monitoring its parameters, including quarter milking (Sandrucci et al., 2007).

Therefore, the present study analysed the milk yield of individual udder quarters in an innovative automatic milking system, in comparison with pipeline milking or parlour milking. The automatic milking system is operational 24 hours a day, 7 days a week, which allows the time available for milking to be used for observation of the herd and improvement of all factors required to increase farm profitability. Milking robots make herd management flexible by giving freedom to organize the day, without the need for fixed milking hours. A voluntary milking system causes differences in cow milking frequency per day, which has been accounted for in the analyses. It is worth noting that scientific publications increasingly often bring up the relationship between 'live organisms' (animals) and 'advanced technology' (automation of livestock production).

The aim of the study was to analyse daily milk yield from udder quarters of automatically milked primiparous and multiparous cows during lactation and with changing milking frequency.

\section{Materials and Methods}

The data used in the present study originated from a database on automatic quarter milking of 160 Polish Holstein-Friesian cows. The herd had an average yield of $9400 \mathrm{~kg}$ milk containing 3.31\% protein and $3.79 \%$ fat. The statistical analyses of the data accounted for 60513 daily milking records (number of cows milked on a given day $\times 365$ days). With a herd milking frequency of around 2.60 times per day, information was obtained from almost 160000 milkings.

Cows were kept in a single free-stall barn, without litter, with slatted floor and cubicles bedded with mattresses; they were fed PMR (partly mixed ration) diets and concentrates at a level to meet maintenance and production requirements. The concentrate, which consisted of maize, soybean meal, rapeseed meal, triticale and mineral-vitamin mixture, was fed in the milking robots. Cows were milked by three automatic milking units.

The data acquired from the herd management system were used to calculate mean daily yield of udder quarters - left front (LF), right front (RF), left rear (LR), and right rear (RR) (kg milk) - and to classify the cows according to:

- Age (primiparous cows, multiparous cows)

- Lactation period $(\leq 100,101-200,201-300,>300$ days)

- Milking frequency $(\leq 2.50,2.51-2.80,>2.80$ times per day)

The relationships of age of cows, lactation period and milking frequency with daily milk yield of udder quarters were calculated. In addition, the effect of age of cows $\times$ lactation period and age of cows $\times$ milking frequency interactions on daily production of udder quarters was determined.

The data were statistically analysed using the GLM procedure of multivariate analysis of variance. Significant differences between the means were determined with the Scheffe test (SAS, 2014).

The following linear model was used:

$$
y_{i j k l}=\mu+a_{i}+b_{j}+c_{k}+d_{l}+(a \times b)_{i j}+(a \times c)_{i k}+e_{i j k l}
$$

where: $\mathrm{y}_{\mathrm{ijkl}}$ - ijkl-th milking,

$\mu$ - overall mean,

$a_{i}$ - fixed effect of $i$-th age of cows (primiparous, multiparous),

$b_{j}$ - fixed effect of $j$-th lactation period ( $\leq 100,101-200,201-300,>300$ days),

$c_{k}$ - fixed effect of k-th milking frequency $(\leq 2.50,2.51-2.80,>2.80)$,

$d_{1}$ - fixed effect of l-th udder quarter (LF, RF, LR, RR),

$(\mathrm{a} \times \mathrm{b})_{\mathrm{ij}}$ - interaction of cow age with lactation period,

$(\mathrm{a} \times \mathrm{c})_{\mathrm{ik}}$ - interaction of cow age with milking frequency, and

$\mathrm{e}_{\mathrm{ijkl}}$ - random error of observation.

Percent differences between individual udder quarters, front and rear quarters, and right and left quarters in daily milk production of primiparous and multiparous cows were also calculated. Furthermore, differences in daily milk yield between front and rear quarters, and between right and left quarters were also determined. 


\section{Results and Discussion}

Analysis of the daily milk yield of mammary quarters in primiparous and multiparous cows revealed significantly higher productivity in older cows (Table 1). At the same time, differences were observed especially in front and rear quarters, but also in left and right quarters. Front quarters (LF and RF) produced significantly less milk in primiparous compared with multiparous cows, by 0.78 and $0.51 \mathrm{~kg}$, respectively. The rear quarters were characterized by higher yield compared with the front quarters.

Higher milk yield was characteristic of rear quarters: $8.22 \mathrm{~kg}$ (left rear) and $7.71 \mathrm{~kg}$ (right rear) in primiparous cows, and 10.06 and $10.47 \mathrm{~kg}$ in multiparous cows, respectively. The difference in daily milk yield was $1.84 \mathrm{~kg}$ for multiparous cows and as much as $2.76 \mathrm{~kg}$ for multiparous cows $(P \leq 0.01)$.

Table 1 Daily milk yield of udder quarters in primiparous and multiparous cows

\begin{tabular}{|c|c|c|c|c|c|c|c|c|c|c|c|c|}
\hline \multirow{3}{*}{ Cows } & \multicolumn{12}{|c|}{ Daily milk yield of udder quarters (milk, kg) } \\
\hline & \multicolumn{3}{|c|}{ Front left } & \multicolumn{3}{|c|}{ Front right } & \multicolumn{3}{|c|}{ Rear left } & \multicolumn{3}{|c|}{ Rear right } \\
\hline & $\mathbf{N}$ & LSM & SE & $\mathbf{N}$ & LSM & SE & $\mathbf{N}$ & LSM & SE & $\mathbf{N}$ & LSM & SE \\
\hline Primiparous & 33436 & $6.75^{\mathrm{A}}$ & 2.56 & 32576 & $6.71^{\mathrm{A}}$ & 2.63 & 32530 & $8.22^{\mathrm{A}}$ & 3.32 & 32094 & $7.71^{\mathrm{A}}$ & 3.11 \\
\hline Multiparous & 27077 & $7.53^{\mathrm{A}}$ & 3.82 & 28198 & $7.22^{\mathrm{A}}$ & 3.66 & 27745 & $10.06^{\mathrm{A}}$ & 4.77 & 27686 & $10.47^{\mathrm{A}}$ & 4.49 \\
\hline
\end{tabular}

$\mathrm{N}$ : number of cows; LSM: linear mean square; SE: standard error

A: means in columns with the same superscript differ significantly at $P \leq 0.01$

The results of the current analyses correspond with the findings of Šlyžius et al. (2013), who investigated the Lithuanian population of Black-and-White cattle and showed that left rear and right rear quarters produced 3.42 and $3.47 \mathrm{~kg}$ milk compared with 2.63 and $2.71 \mathrm{~kg}$ milk per milking in left front and right front quarters. The herd was milked twice daily.

The production level in front and rear quarters was fairly uniform for both primiparous and multiparous cows. With advancing lactation (from $\leq 100$ to $>300$ days), the milk yield of all mammary quarters was found to decrease significantly $(P \leq 0.01)$ (Table 2). The lowest decrease was in left front quarters (by $3.40 \mathrm{~kg}$ from 8.61 to $5.21 \mathrm{~kg}$ ) and the highest in right rear quarters (by $4.35 \mathrm{~kg}$ from 11.00 to $6.65 \mathrm{~kg}$ ). Analysis of front and rear quarters separately showed that the milk production of left and right quarters was consistent in successive lactation periods. This relationship was most evident in cows entering lactation (in the first lactation period $\leq 100$ days). With regard to the front quarters, left quarters produced $8.61 \mathrm{~kg}$ milk and right quarters $8.67 \mathrm{~kg}$ milk per day on average. The same milk production $(11.00 \mathrm{~kg} / \mathrm{day})$ was observed for the rear quarters. In this case, the lack of differences in production level between left and right quarters persisted in the second lactation period (101-200 days) at 9.95 and $9.96 \mathrm{~kg}$ milk/day, respectively.

Table 2 Daily milk yield of cow udders in successive lactation periods

\begin{tabular}{|c|c|c|c|c|c|c|c|c|c|c|c|c|}
\hline \multirow{3}{*}{$\begin{array}{l}\text { Lactation } \\
\text { periods } \\
\text { (days) }\end{array}$} & \multicolumn{12}{|c|}{ Daily milk yield of udder quarters (milk, kg) } \\
\hline & \multicolumn{3}{|c|}{ Front left } & \multicolumn{3}{|c|}{ Front right } & \multicolumn{3}{|c|}{ Rear left } & \multicolumn{3}{|c|}{ Rear right } \\
\hline & $\mathrm{N}$ & LSM & SE & $\mathbf{N}$ & LSM & SE & $\mathbf{N}$ & LSM & SE & $\mathrm{N}$ & LSM & SE \\
\hline$\leq 100$ & 14698 & $8.61^{\mathrm{ABC}}$ & 3.36 & 14702 & $8.67^{\mathrm{ABC}}$ & 3.24 & 14549 & $11.00^{\mathrm{ABC}}$ & 4.38 & 14749 & $11.00^{\mathrm{ABC}}$ & 4.19 \\
\hline 101-200 & 15683 & $7.90^{\mathrm{ADE}}$ & 3.15 & 15964 & $7.63^{\mathrm{ADE}}$ & 2.97 & 15562 & $9.95^{\mathrm{ADE}}$ & 4.08 & 15724 & $9.96^{\mathrm{ADE}}$ & 3.91 \\
\hline 201-300 & 14203 & $6.77^{\mathrm{BDF}}$ & 2.77 & 14278 & $6.46^{\mathrm{BDF}}$ & 2.70 & 14096 & $8.60^{\mathrm{BDF}}$ & 3.63 & 14055 & $8.32^{\mathrm{BDF}}$ & 3.40 \\
\hline$>300$ & 15929 & $5.21^{\mathrm{CEF}}$ & 2.38 & 15830 & $5.09^{\mathrm{CEF}}$ & 2.47 & 16068 & $6.83^{\mathrm{CEF}}$ & 3.23 & 15252 & $6.65^{\mathrm{CEF}}$ & 3.19 \\
\hline
\end{tabular}

$\mathrm{N}$ : number of cows; LSM: linear mean square; SE: standard error

$\mathrm{A}, \mathrm{B}, \mathrm{C}, \mathrm{D}, \mathrm{E}, \mathrm{F}$ : means in columns with the same superscript differ significantly at $P \leq 0.01$ 
As milking frequency increased, the milk yield of individual quarters rose $(P \leq 0.01)$ markedly (Table 3$)$. In the front quarters, both left and right quarters showed similar milk yields for milking frequency of fewer than 2.50 times/day and more than 2.80 times/day. The left front quarters produced 6.23 and $7.89 \mathrm{~kg}$ milk/day compared with 6.27 and $7.93 \mathrm{~kg}$ for the right front quarters, respectively. A similar relationship was observed for rear quarters, but here the differences were slightly greater. They were $0.10 \mathrm{~kg}$ milk/day for milking frequency of fewer than 2.50 times/day and $0.12 \mathrm{~kg}$ milk/day for the highest milking frequency. Despite the lower production of front compared with rear quarters, the difference between the left and right quarters was similar at $0.43 \mathrm{~kg}$ (front quarters) and $0.41 \mathrm{~kg}$ (rear quarters).

Table 3 Daily milk yield of cow udder quarters depending on milking frequency

\begin{tabular}{|c|c|c|c|c|c|c|c|c|c|c|c|c|}
\hline \multirow{3}{*}{$\begin{array}{l}\text { Milking } \\
\text { frequency }\end{array}$} & \multicolumn{12}{|c|}{ Daily milk yield of udder quarters (milk, kg) } \\
\hline & \multicolumn{3}{|c|}{ Front left } & \multicolumn{3}{|c|}{ Front right } & \multicolumn{3}{|c|}{ Rear left } & \multicolumn{3}{|c|}{ Rear right } \\
\hline & $\mathbf{N}$ & LSM & SE & $\mathbf{N}$ & LSM & SE & $\mathbf{N}$ & LSM & SE & $\mathrm{N}$ & LSM & SE \\
\hline$\leq 2.50$ & 20504 & $6.23^{\mathrm{AB}}$ & 2.97 & 21113 & $6.27^{A B}$ & 2.91 & 20962 & $7.82^{\mathrm{AB}}$ & 3.86 & 20493 & $8.04^{\mathrm{AB}}$ & 4.03 \\
\hline $2.51-2.80$ & 26572 & $7.37^{\mathrm{AC}}$ & 2.91 & 25399 & $6.94^{\mathrm{AC}}$ & 2.89 & 25978 & $9.29^{\mathrm{AC}}$ & 3.97 & 26026 & $8.88^{\mathrm{AC}}$ & 3.70 \\
\hline$>2.80$ & 13437 & $7.89^{\mathrm{BC}}$ & 3.77 & 14232 & $7.93^{\mathrm{BC}}$ & 3.67 & 13335 & $10.56^{\mathrm{BC}}$ & 4.40 & 13261 & $10.66^{\mathrm{BC}}$ & 4.25 \\
\hline
\end{tabular}

$\mathrm{N}$ : number of cows; LSM: linear mean square; SE: standard error

A, B, C: means in columns with the same superscript differ significantly at $P \leq 0.01$

In the next lactation periods, statistically significant $(P \leq 0.01)$ differences in the milk yield of mammary quarters were found between primiparous and multiparous cows (Table 4). Up to 200 days of lactation, the yield of individual quarters was markedly higher in multiparous compared with primiparous cows. In the first period of lactation, front quarters of primiparous cows produced $7.67-7.84 \mathrm{~kg}$ milk/day compared with 9.28$9.30 \mathrm{~kg}$ in multiparous cows. The corresponding figures in the second period of lactation were 7.51-7.72 and 7.74-8.08 kg milk/day. An analogous situation existed, with a higher production level, for the rear quarters. Starting from the third period of lactation (201-300 days), quarter yields were higher in primiparous cows. Their front and rear quarters produced 6.91-7.16 and 8.71-8.81 kg milk/day (201-300 days of lactation) and 5.48-5.56 and 7.04-7.22 kg milk/day (>300 days of lactation), respectively. In multiparous cows, the respective quarter yields were $5.88-6.24$ and $7.93-8.46$, as well as $3.86-4.40$ and $5.82-6.51 \mathrm{~kg}$ milk per day.

Table 4 Daily milk yield of udder quarters in primiparous and multiparous cows in successive lactation periods

\begin{tabular}{|c|c|c|c|c|c|c|c|c|c|c|c|c|c|}
\hline \multirow{3}{*}{$\begin{array}{l}\text { Lactation } \\
\text { periods } \\
\text { (days) }\end{array}$} & \multirow{3}{*}{ Cows } & \multicolumn{12}{|c|}{ Daily milk yield of udder quarters (milk, kg) } \\
\hline & & \multicolumn{3}{|c|}{ Front left } & \multicolumn{3}{|c|}{ Front right } & \multicolumn{3}{|c|}{ Rear left } & \multicolumn{3}{|c|}{ Rear right } \\
\hline & & $\mathbf{N}$ & LSM & SE & $\mathbf{N}$ & LSM & SE & $\mathbf{N}$ & LSM & SE & $\mathbf{N}$ & LSM & SE \\
\hline \multirow{2}{*}{$\leq 100$} & Primiparous & 5565 & $7.84^{\mathrm{A}}$ & 2.49 & 5531 & $7.67^{\mathrm{A}}$ & 2.45 & 5530 & $8.57^{\mathrm{A}}$ & 3.31 & 5619 & $8.58^{A}$ & 2.95 \\
\hline & Multiparous & 9133 & $9.30^{\mathrm{A}}$ & 3.62 & 9171 & $9.28^{\mathrm{A}}$ & 3.50 & 9019 & $12.53^{\mathrm{A}}$ & 4.28 & 9130 & $12.49^{\mathrm{A}}$ & 4.14 \\
\hline \multirow{2}{*}{ 101-200 } & Primiparous & 7772 & $7.72^{\mathrm{B}}$ & 2.43 & 7672 & $7.51^{\mathrm{B}}$ & 2.55 & 7548 & $8.95^{\mathrm{B}}$ & 3.34 & 7481 & $8.61^{\mathrm{B}}$ & 2.93 \\
\hline & Multiparous & 7911 & $8.08^{B}$ & 3.71 & 8292 & $7.74^{\mathrm{B}}$ & 3.31 & 8014 & $10.88^{\mathrm{B}}$ & 4.47 & 8243 & $11.19^{B}$ & 4.26 \\
\hline \multirow{2}{*}{$201-300$} & Primiparous & 8192 & $7.16^{\mathrm{C}}$ & 2.31 & 7949 & $6.91^{c}$ & 2.53 & 7902 & $8.71^{\mathrm{C}}$ & 3.38 & 7798 & $8.81^{C}$ & 3.02 \\
\hline & Multiparous & 3011 & $6.24^{C}$ & 3.22 & 6329 & $5.88^{C}$ & 2.80 & 6194 & $8.46^{C}$ & 3.93 & 6257 & $7.93^{C}$ & 3.84 \\
\hline \multirow{2}{*}{$>300$} & Primiparous & 11907 & $5.48^{\mathrm{D}}$ & 2.32 & 11424 & $5.56^{\mathrm{D}}$ & 2.40 & 11550 & $7.22^{\mathrm{D}}$ & 3.03 & 11196 & $7.04^{\mathrm{D}}$ & 2.98 \\
\hline & Multiparous & 4022 & $4.40^{\mathrm{D}}$ & 2.40 & 4406 & $3.86^{\mathrm{D}}$ & 2.21 & 4518 & $5.82^{\mathrm{D}}$ & 3.48 & 4056 & $6.51^{\mathrm{D}}$ & 3.66 \\
\hline
\end{tabular}

$\mathrm{N}$ : number of cows; LSM: linear mean square; SE: standard error

A, B, C, D: means in columns with the same superscript differ significantly at $P \leq 0.01$ 
Comparisons of the milk production of quarters in primiparous and multiparous cows in successive lactation periods showed that it gradually decreased. In the youngest cows, the yield of left front quarters decreased by $2.36 \mathrm{~kg} / \mathrm{day}$ (from 7.84 to 5.48), and that of right front quarters by $2.11 \mathrm{~kg} / \mathrm{day}$ (from 7.67 to 5.56). In multiparous cows, milk yield from quarters showed a more rapid decline with advancing lactation. It decreased by $4.90 \mathrm{~kg} /$ day for left front quarters, and by $5.42 \mathrm{~kg} /$ day for right front quarters. A similar situation occurred in these cows for rear quarters, but the decrease in milk yield was $6.71 \mathrm{~kg}$ (left) and $5.98 \mathrm{~kg}$ milk/day (right). Such regular relationships were not observed when analysing the daily yield of rear quarters in the primiparous cows. Daily milk production of rear quarters increased from $8.57 \mathrm{~kg}$ ( $\leq 100$ days of lactation) to $8.95 \mathrm{~kg}$ (101-200 days of lactation), but then decreased in successive lactation periods. In turn, milk production of right rear quarters increased from the beginning of lactation to the third period of lactation (from $8.58 \mathrm{~kg}$ to $8.81 \mathrm{~kg}$ ), and decreased in the last period of lactation (to $7.04 \mathrm{~kg}$ milk/day).

In a study by Sitkowska et al. (2014), lactation stage caused differences in the milk yield of front and rear quarters. The authors analysed individual quarter milkings and observed small disparities between the milk yield of front and rear quarters, namely $0.31-0.46 \mathrm{~kg}$ in primiparous cows and $0.52-0.57 \mathrm{~kg}$ in multiparous cows. This could be because the analysed population of cows was characterized by an average production level. The mean yield per single milking was $7-10 \mathrm{~kg}$ of milk.

The results given in Table 5 show differences in the milk production of udder quarters between primiparous and multiparous cows within classes of milking frequency per day $(P \leq 0.01)$. For the lowest number of milkings per day ( $\leq 2.50$ times), the milk production of front quarters was higher in primiparous cows, namely 6.37 and $6.29 \mathrm{~kg}$ (left and right) compared with 6.03 and $6.28 \mathrm{~kg}$ in multiparous cows. Statistically significant differences occurred only for left front quarters. In the other two milking frequency classes, higher milk yield of quarters, especially for the highest number of milkings per day, was noted in multiparous cows.

Table 5 Daily milk yield of udder quarters in primiparous and multiparous cows in successive classes of milking frequency

\begin{tabular}{|c|c|c|c|c|c|c|c|c|c|c|c|c|c|}
\hline \multirow{3}{*}{$\begin{array}{l}\text { Milking } \\
\text { frequency }\end{array}$} & \multirow{3}{*}{ Cows } & \multicolumn{12}{|c|}{ Daily milk yield of udder quarters (milk, kg) } \\
\hline & & \multicolumn{3}{|c|}{ Front left } & \multicolumn{3}{|c|}{ Front right } & \multicolumn{3}{|c|}{ Rear left } & \multicolumn{3}{|c|}{ Rear right } \\
\hline & & $\mathbf{N}$ & LSM & SE & $\mathbf{N}$ & LSM & SE & $\mathbf{N}$ & LSM & SE & $\mathbf{N}$ & LSM & SE \\
\hline \multirow{2}{*}{$\leq 2.50$} & Primiparous & 12160 & $6.37^{A}$ & 2.50 & 11695 & 6.29 & 2.39 & 11729 & $7.34^{\mathrm{A}}$ & 3.11 & 11448 & $7.21^{\mathrm{A}}$ & 3.07 \\
\hline & Multiparous & 8344 & $6.03^{\mathrm{A}}$ & 3.54 & 9418 & 6.28 & 3.46 & 9233 & $8.43^{\mathrm{A}}$ & 4.56 & 9045 & $9.09^{A}$ & 4.77 \\
\hline \multirow{2}{*}{$2.51-2.80$} & Primiparous & 16178 & $6.94^{\mathrm{B}}$ & 2.43 & 15659 & 6.92 & 2.81 & 15917 & $8.73^{\mathrm{B}}$ & 3.49 & 15674 & $7.88^{\mathrm{B}}$ & 3.14 \\
\hline & Multiparous & 10394 & $8.02^{\mathrm{B}}$ & 3.42 & 9740 & 6.96 & 3.01 & 10061 & $10.18^{\mathrm{B}}$ & 4.48 & 10352 & $10.40^{\mathrm{B}}$ & 3.96 \\
\hline \multirow{2}{*}{$>2.80$} & Primiparous & 5098 & $7.02^{c}$ & 2.94 & 5222 & $7.00^{c}$ & 2.47 & 4884 & $8.63^{C}$ & 2.79 & 4972 & $8.29^{C}$ & 2.96 \\
\hline & Multiparous & 8339 & $8.43^{C}$ & 4.11 & 9040 & $8.47^{C}$ & 4.11 & 8451 & $11.68^{C}$ & 4.76 & 8289 & $12.08^{C}$ & 4.28 \\
\hline
\end{tabular}

$\mathrm{N}$ : number of cows; LSM: linear mean square; SE: standard error

A, B, C: means in columns with the same superscript differ significantly at $P \leq 0.01$

Hopster et al. (2002) stated that the lower milk yield in primiparous cows is determined physiologically. At the same time, owing to the higher milking frequency in the automatic milking system, these cows are able to show higher milking yields in subsequent lactations (Nogalski et al., 2011; Wright et al., 2013).

Slightly different relationships were characteristic of the milk yield of rear quarters in primiparous and multiparous cows along with the changing milking frequency during the day. Regardless of the number of milkings, both the left rear and right rear quarters in multiparous cows produced more milk per day compared with primiparous cows. These disparities increased with the growing number of milkings per day. The milk production of left rear quarters in multiparous compared with primiparous cows in the consecutive milking frequency classes was higher by $1.09,1.45$ and $3.05 \mathrm{~kg}$ milk per day, while in right rear quarters by 1.88, 2.52 and $3.79 \mathrm{~kg}$ milk per day, respectively.

The contribution of front and rear quarters to daily production was $45.8-54.2 \%$ in primiparous cows and $41.8-58.2 \%$ in multiparous cows (Table 6).

These findings are consistent with earlier studies, and the results obtained by multiparous cows reflect their high suitability for machine milking (Tančin et al., 2007b; Kuczaj, 2010; Šlyžius et al., 2013). The 
percentage difference in daily milk production of front and rear quarters was 18.35 for primiparous cows and $39.18 \%$ for multiparous cows; the values for left and right quarters were 3.10 and $0.60 \%$, respectively. The differences in the daily milk production of front and rear quarters are higher, especially for multiparous cows, than those reported by Stankūnienè et al. (2008). Earlier research confirms, however, that rear quarters produce considerably more milk than front quarters, and are characterized by longer milking time, higher production peak and higher mean milk flow intensity (Tancin et al., 2006).

Table 6 Differences in the contribution of udder quarters to daily milk production

\begin{tabular}{|c|c|c|c|c|c|}
\hline \multirow{2}{*}{$\begin{array}{l}\text { Cows } \\
\text { Primiparous }\end{array}$} & \multicolumn{5}{|c|}{ Contribution of udder quarters to daily milk production (\%) } \\
\hline & \multirow{2}{*}{$\begin{array}{c}\text { Individual } \\
(F L+F R / R L+R R)\end{array}$} & 22.97 & 22.83 & 27.97 & 26.23 \\
\hline Multiparous & & 21.34 & 20.46 & 28.52 & 29.68 \\
\hline Primiparous & \multirow{2}{*}{$\begin{array}{c}\text { Front/Rear } \\
(\mathrm{FL}+\mathrm{FR} / \mathrm{RL}+\mathrm{RR})\end{array}$} & \multicolumn{2}{|c|}{45.80} & \multicolumn{2}{|c|}{54.20} \\
\hline Multiparous & & \multicolumn{2}{|c|}{41.80} & \multicolumn{2}{|c|}{58.20} \\
\hline Primiparous & \multirow{2}{*}{$\begin{array}{c}\text { Left/Right } \\
\text { (FL+FR/RL+RR) }\end{array}$} & \multicolumn{2}{|c|}{50.94} & \multicolumn{2}{|c|}{49.06} \\
\hline Multiparous & & \multicolumn{2}{|c|}{49.86} & \multicolumn{2}{|c|}{50.14} \\
\hline \multicolumn{6}{|c|}{$\%$ difference in daily milk yield of front and rear / left and right quarters } \\
\hline \multicolumn{2}{|r|}{ Primiparous } & \multicolumn{4}{|c|}{$18.35 / 3.10$} \\
\hline \multicolumn{2}{|r|}{ Multiparous } & \multicolumn{4}{|c|}{$39.18 / 0.60$} \\
\hline
\end{tabular}

\section{Conclusions}

The differences between the milk production of front and rear udder quarters, and also between left and right quarters, are determined by various factors, such as age of cows, lactation period, and milking frequency. Account should also be taken of the cows' individual characteristics, anatomy, and physiological efficiency of the udders, which makes each udder quarter differ in the amount of milk produced and milking speed. The practical application of automatic milk collection (milking robots, technologically advanced milking parlours) enables the quarter milking parameters to be monitored closely.

\section{Acknowledgements}

Research carried out within statutory research BS-7/2016, Department of Cattle Breeding, UTP University of Science and Technology, Bydgoszcz, Poland.

\section{Conflict of Interest Declaration}

The author declares that he has no conflicts of interest with regard to this work.

\section{References}

Atasever, S. \& Erdem, H., 2009. Association between subclinical mastitis markers and body condition scores of Holstein cows in the Black Sea region. Turk. J. Anim. Vet. Adv. 8, 476-480.

Bach, A. \& Busto, I., 2005. Effects on milk yield of milking interval regularity and teat cup attachment failures with robotic milking systems. J. Dairy Res. 72, 101-106.

Berglund, I., Pettersson, G., Östensson, K. \& Svennersten-Sjaunja K., 2007. Quarter milking for improved detection of increased SCC. Reprod. Dom. Anim. 42, 427-432.

Forsbäck, L., Lindmark-Mänsson, H., Andren, A., Akerstedt, M., Andree, L. \& Svennersten-Sjaunja, K. 2010., Day-to-day variation in milk yield and milk composition at the udder quarter level. J. Dairy Sci. 93, 3569-3577.

Forsbäck, L., Lindmark-Mansson, H., Svennersten-Sjaunja, K., Bach Larsen, L. \& Andrén, A., 2011. Effect of storage and separation of milk at udder quarter level on milk composition, proteolysis, and coagulation properties in relation to somatic cell count. J. Dairy Sci. 94, 5341-5349.

Haghkhah, M., Ahmadi, M.R., Gheisari, H.R. \& Kadivar, A., 2011. Preliminary bacterial study on subclinical mastitis and teat condition in dairy herds around Shiraz. Turk. J. Vet. Anim. Sci. 35, 387-394.

Hopster, H.R.M.B., Bruckmaier, R.M., Van der Werf, J.T.N., Korte, S.M., Macuhova, J., Korte-Bouws, G. \& Van Reenen, C.G., 2002. Stress responses during milking: Comparing conventional and automatic milking in primiparous dairy cows. J. Dairy Sci. 85, 3206-3216.

Jędruś, A., 2013. Modern milking systems in small barns. Hod. i Chów Bydła 6, 32-35 (in Polish).

Kuczaj, M., 2010. Cattle breeding, EU and national standards. Wyd. UP Wrocław (in Polish).

Nogalski, Z., Czerpak, K. \& Pogorzelska, P., 2011. Effect of automatic and conventional milking on somatic cell count and lactation traits in primiparous cows. Ann. Anim. Sci. 11, 433-441. 
Pritchard, T., Coffey, M., Mrode, R. \& Moore, E., 2010. Wall: Genetic parameters of udder health traits in Holstein Friesian UK dairy cattle. http://www.kongressband.de/wcgalp2010/assets/pdf/0487.pdf

Sandrucci, A., Tamburini, A., Bava, L. \& Zucali, M., 2007. Factors affecting milk flow traits in dairy cows: Results of a field study. J. Dairy Sci. 90, 1159-1167.

SAS Institute Inc., 2014. SAS/STAT® 9.4 User's guide.: SAS Institute Inc., Cary, NC.

Sitkowska, B., Piwczyński, D., Brzozowski, M. \& Aerts, J., 2016. Quarter milking in primiparous and multiparous cows. Rocz. Nauk. Zoot. 12 (4), 35-48 (in Polish).

Šlyžius, E., Juozaitienè, V., Tušas, S., Juozaitis, A. \& Žymantienè, J., 2013. Relation of udder quarter development with daily milk yield, composition and somatic cell count. Vet. Med. Zoot. 63, (85), 76-80.

Stankūnienè, V., Tacas, J. \& Mišeikienè, J., 2008. Dairy farm owner. In: Lithuanian Veterinary Academy. Milking Training Center, 32-39.

Szencziová, I., Strapák, P., Stádník, L., Ducháček, J. \& Beran, J., 2013. Relationship of udder and teat morphology to milking characteristics and udder health determined by ultrasonographic examinations in dairy cows. Ann. Anim. Sci. 13, 783-795.

Tancin, V., Ipema, B., Hogeverf, P. \& Macuhova, J., 2006. Sources of variation in milk flow characteristics at udder and quarter levels. J. Dairy Sci. 89 (3), 978-988.

Tancin, V., Uhrincat, M., Macuhova, L. \& Bruckmaier, R.M., 2007a. Effect of pre-stimulation on milk flow pattern and distribution of milk constituents at a quarter levels. Czech J. Anim. Sci. 52, 117-121.

Tancin, V., Uhrinča, M., Mihina, S., Sudzinová, J., Foltys, V. \& Tančinová, D., 2007b. Somatic cell count and quarter milk flow parameters from udder of dairy cows. Slovak J. Anim. Sci. 40, 79-82.

Tilki, M., Inal, S., Colak, M. \& Garip, M., 2005. Relationships between milk yield and udder measurements in Brown Swiss Cows. Turk. J. Vet. Anim. Sci. 29, 75-81.

Weiss, D., Weinfurtner, M. \& Bruckmaier, R.M., 2004. Teat anatomy and its relationship with quarter and udder milk flow characteristics in dairy cows. J. Dairy Sci. 87, 3280-3289.

Wright, J.B., Wall, E.H. \& McFadden, T.B., 2013. Effects of increased milking frequency during early lactation on milk yield and udder health of primiparous Holstein heifers. J. Anim. Sci. 91, 195-202. 